\title{
MATERNAL AND NEONATAL EFFECTS OF METHOXYFLURANE, NITROUS OXIDE AND LUMBAR EPIDURAL ANAESTHESIA FOR CAESAREAN SECTION
}

\author{
Richard J. Palahniuk, John Scatliff, Diane Biehl, Henry Wiebe, and \\ K. SANKARAN
}

\section{INTRODUCTION}

General anaesthesia continues to be widely used for Caesarean section. Despite the reduction of neonatal depression and the decreased risk of maternal aspiration with regional anaesthetic techniques, ${ }^{1,2}$ there are many indications for general anaesthesia for Caesarean section. ${ }^{3}$ Patient or anaesthetist preference, inexperience with regional blocks, emergency situations where regional blocks are contra-indicated and failed regional anaesthetics are but a few of the reasons for the continued use of general anaesthesia for Caesarean section.

No one technique of general anaesthesia has been demonstrated to be superior in terms of neonatal outcome or maternal acceptance. Major disadvantages with any general anaesthetic technique include the development of foetal acidosis, lower neonatal Apgar scores as the anaesthetic time is prolonged ${ }^{4,5}$ and maternal awareness if too light an anaesthetic technique is used. ${ }^{6}$ Several authors have suggested that increasing the maternal inspired oxygen concentration $\left(\mathrm{F}_{\mathrm{O}_{2}}\right)$ may be an important factor in increasing foetal arterial oxygenation and improving neonatal outcome. ${ }^{7,8}$ Reducing the maternal nitrous oxide in order to administer a high oxygen concentration has required supplementation of the inspired gas mixture with volatile anaesthetics such as halothane or methoxyflurane to prevent maternal awareness. ${ }^{0-11}$ This has not been associated with any increase in the amount of neonatal depression. ${ }^{12}$

We decided to compare three anaesthetic techniques in order to be able to make a more logical choice of anaesthesia for Caesarean section.

1. Thiopentone induction followed by nitrous oxide ( 70 per cent) - oxygen ( 30 per cent) maintenance.

2. Thiopentone induction followed by methoxyflurane (0.2-0.5 per cent) oxygen ( 99 per cent) maintenance.

3 . Epidural anaesthesia with oxygen supplementation.

Over the past three years, perinatologists have indicated that more detailed neurophysiological testing of the newborn in the first few days of life may reveal subtle drug effects that the Apgar score may not distinguish. ${ }^{13-15}$ We therefore

Presented at the American Society of Anesthesiologists' Meeting, San Francisco, October, 1976. Supported, in part, by a grant from Abbott Laboratories, Montreal, Quebec.

From the Departments of Anaesthesia and Paediatrics, University of Manitoba and Health Sciences Centre, Winnipeg, Manitoba, Canada.

Address reprint requests to Dr. R. J. Palahniuk, Department of Anaesthesia, Health Sciences Centre, 700 William Avenue, Winnipeg, Canada, R3E $0 Z 3$.

Canad. Anaesth. Soc. J., vol. 24, no. 5, September 1977 
included neurophysiological testing as an important part of the comparison of these newborns.

\section{Patient SELECTion}

We studied 37 patients undergoing elective Caesarean section within two weeks of term (38-40 weeks gestation). No patient with any systemic disease or obstetrical complication which might impair placental function or foetal well-being was included in the study. All patients were informed about the nature of the study and signed a consent form. The choice of epidural or general anaesthesia was decided between the patient and the attending anaesthetist. When a general anaesthetic was chosen, the patients were assigned to receive either the methoxyflurane or nitrous oxide in a random manner.

\section{METHOD}

No patient was premedicated. All patients were transported to the operating room in the lateral position and kept in this position until shortly before induction of annesthesia. In the epidural group, 15 degree left lateral tilt was maintained throughout the operative period by a wedge under the right buttock.

In the general anaesthesia groups, all patients were prepared and draped prior to induction of anaesthesia. Each was pre-oxygenated by mask for three minutes, induced using thiopentone $4 \mathrm{mg} / \mathrm{kg}$ and given succinylcholine $100 \mathrm{mg}$ for intubation. Maintenance then consisted of either nitrous oxide ( 70 per cent) in oxygen ( 30 per cent) or methoxyflurane (up to 0.5 per cent) in oxygen ( 99 per cent) and ventilation at $10 \mathrm{ml} / \mathrm{kg}$ body weight with a rate of eight per minute. Paralysis was maintained with either a succinylcholine infusion or a bolus of d-tubocurarine $(.25 \mathrm{mg} / \mathrm{kg})$. Once the umbilical cord was clamped and the baby handed to the neonatologist, the study period was considered completed and the anaesthetic technique was changed at the discretion of the individual anaesthetist.

In the epidural group, a lumbar epidural catheter was inserted with the patient in the lateral position. Carbonated lidocaine ( 1.73 per cent) with epinephrine $1 / 200,000$ ) was used as the local anaesthetic in a dose sufficient to obtain anaesthesia from S5 to T4-T6. Supplemental oxygen was administered to all patients in this group by means of nasal cannulae. If hypotension (systolic blood pressure below $100 \mathrm{~mm} \mathrm{Hg}$ ) occurred, prompt restoration of normal blood pressure was obtained with further left uterine displacement, intravenous fluids and, if necessary, intravenous ephedrine ( 10 to $25 \mathrm{mg}$ ). No patient remained hypotensive for longer than 1 to 2 minutes. Four patients required ephedrine to correct hypotension, but as the results in these patients did not differ from those of the others in the epidural group, all patients were considered together for the analysis of the data.

In all patients maternal blood pressure was monitored every minute using the Arteriosonde apparatus. Umbilical artery and vein $\mathrm{Po}_{2}, \mathrm{Pco}_{2}$, and $\mathrm{pH}$ were determined on blood samples obtained from a double-clamped segment of umbilical cord obtained at the time of delivery. All blood gas and $\mathrm{pH}$ determinations were made using an IL model $113 \mathrm{pH}$ /gas analyzer immediately after the blood samples 
were obtained. Base excess was calculated for each blood sample. Apgar scores were determined at one minute and five minutes by a neonatologist with no knowledge of the type of anaesthesia used in the mother. Neurophysiological evaluation of the newborn was performed at six hours and twenty-four hours of age by the method described by Scanlon et al. ${ }^{1: 3}$ and consisted of a detailed extensive neurological evaluation of the baby in five areas:

1. Muscle tone in the arms, legs, and trunk including an overall assessment of the infant's tone.

2. Moro, sucking and rooting reflexes.

3. Infant response to a pin-prick and the sound of a bell.

4. Observer's assessment of alertness, and

5. Overall degree of neurological response (general assessment).

The evaluation was performed by a neonatologist who had no knowledge of the type of anaesthesia administered to the mother. To facilitate analysis and presentation of the data, individual tests of muscle tone (arms, legs and trunk), reflexes (Moro, sucking and rooting) and infant response to stimuli (pin-prick and bell) were grouped together and are presented in the figures as muscle tone, reflex activity and response to stimuli.

In addition, mothers in the two general anaesthesia groups had arterial blood samples obtained at the time of chord clamping for determination of blood gases and $\mathrm{pH}$, and calculation of base excess. The mothers also had venous blood samples taken before induction of anaesthesia (control sample) and at twentyfour hours after the anaesthetic for determination of BUN, serum creatinine and serum fluoride levels. Additional maternal serum fluoride analyses were performed at the time of cord clamping and two hours after delivery, and foetal fluoride level was measured in a sample of umbilical vein blood. Serum fluoride was measured using the ion-specific electrode. ${ }^{16}$

Each mother was interviewed on the first post-operative day with particular reference to the occurrence of recall.

Data were analysed using a Student's t-test for unpaired data (blood gases, $\mathrm{pH}$, base excess, BUN, serum creatinine, serum fluoride and haemoglobin) or the Chisquare test (neuro-physiological testing) $. \mathrm{p}<0.05$ was considered significant.

\section{RESULTS}

The patient ages, induction to delivery intervals (IDI) for the general anaesthesia groups and the incidence of low Apgar scores for the three groups are shown in Table I. There was no difference between the ages, IDI, and neonatal Apgar scores.

The blood gases at delivery are shown in Table II. Maternal arterial $\mathrm{Pa}_{\mathrm{O}_{2}}$ was much higher in the MOF group compared to the $\mathrm{N}_{2} \mathrm{O}$ group as might be expected from the higher $\mathrm{F}_{\mathrm{O}_{2}}$. This is reflected as higher umbilical vein and artery $\mathrm{Pa}_{\mathrm{O}_{2}}$ in the foetus. $\mathrm{PCO}_{2}$ and $\mathrm{pH}$ values show no difference between the groups, although there is a tendency toward a lower base excess (more metabolic acidosis) in the foetal blood in the nitrous oxide and epidural groups. 
TABLE I

PATIENT INFORMATION

\begin{tabular}{lccc}
\hline & MOF & $\mathrm{N}_{2} \mathrm{O}$ & EPI \\
\hline $\mathrm{N}$ & 12 & 11 & 14 \\
Age (yrs. \pm S.D.) & $29.3 \pm 4.6$ & $27.5 \pm 5.0$ & $30.6 \pm 4.4$ \\
IDI (Min. \pm S.D.) & $8.0 \pm 2.9$ & $8.3 \pm 2.9$ & - \\
Apgar score <7 & 1 & 2 & 1 \\
1 min & 0 & 0 & 0 \\
5 min & & & \\
\hline
\end{tabular}

Matemal blood values are presented in Table III and maternal serum fuoride level in the MOF and $\mathrm{N}_{2} \mathrm{O}$ groups is illustrated in Figure 1. Serum fluoride levels in the mother did not change in the nitrous oxide group, but rose significantly in the patients anaesthetized with methoxyflurane. Peak levels were measured at two hours after delivery (mean $=11.15 \mu \mathrm{mol}$ with the highest measured level $=$ $17.5 \mu \mathrm{mol}$ ). Foetal levels remained low in both groups.

Results of the neurophysiological testing are illustrated in Figures 2 to 6 . These can be summarized as illustrating a tendency toward poorer muscle tone, alertness and general assessment in the $\mathrm{N}_{2} \mathrm{O}$ group and poor tone in the epidural group, with tone at six hours being significantly better in the MOF group and alertness at 6 and 24 hours being significantly poorer in the $\mathrm{N}_{2} \mathrm{O}$ group. Although general assessment was not significantly poorer in the $\mathrm{N}_{2} \mathrm{O}$ group at 6 or 24 hours, the results approached significance at 24 hours. Generally there was improvement in the scores from 6 to 24 hours in each group.

Although no patient had absolute recall for the operative period, one mother in the methoxyflurane group had vague recall of voices. She was unsure whether this was during the operative period or during recovery from anaesthesia. She did not experience any pain or remember any part of the operation itself.

\section{Discussion}

Although there was no obvious superiority for one anaesthetic technique over the others, several trends must make one consider these results in the face of our clinical practice. The methoxyflurane group clearly had improved matemal and foetal oxygenation over the $\mathrm{N}_{2} \mathrm{O}$ group. There also was a tendency towards poorer tone, poorer alertness and poorer general assessment by the neonatologist for the $\mathrm{N}_{2} \mathrm{O}$ group. These results agree with those of other investigators who have reported better oxygenation, Apgar scores and time to sustained respirations when maternal $\mathrm{FI}_{\mathrm{O}_{2}}$ is increased. There is currently a trend towards increasing maternal $\mathrm{FI}_{\mathrm{O}_{2}}$ by reducing the $\mathrm{N}_{2} \mathrm{O}$ concentration administered. This of course has the distinct danger of maternal awareness, but it appears that this can be circumvented by adding a volatile anaesthetic. One mother in the methoxyflurane-oxygen group gave a vague history of voice recall during the anaesthetic period, although she was unsure whether this was during the anaesthesia or during recovery. She had no memory of pain or of the surgery. The long-term significance of this type of neuro- 


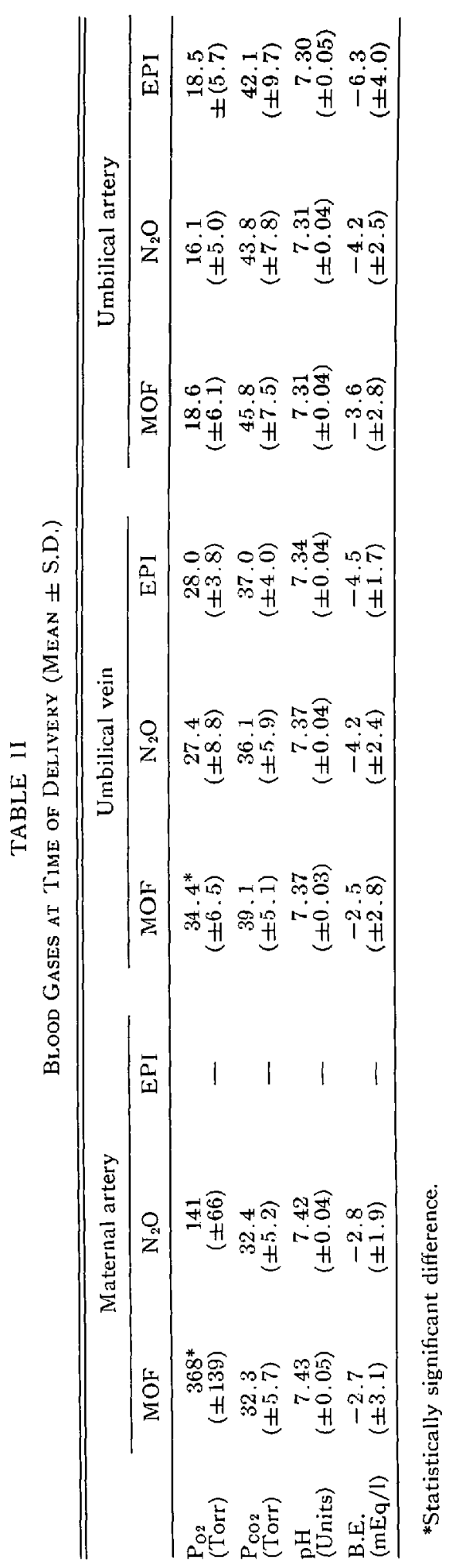


TABLE III

LABORATORY DATA

\begin{tabular}{lccc}
\hline \hline & MOF & $\mathrm{N}_{2} \mathrm{O}$ & EPI \\
\hline Haemoglobin (gm. \% $\%$ S.D.) & & & \\
$\quad$ Control & $12.40 \pm 0.9$ & $11.70 \pm 1.1$ & $12.00 \pm 0.6$ \\
24 hours & $12.00 \pm 1.3$ & $10.90 \pm 1.4$ & $11.60 \pm 0.7$ \\
BUN (mg \% $\%$ S.D.) & $8.40 \pm 1.2$ & $8.70 \pm 2.1$ & - \\
Control & $5.80 \pm 1.0$ & $6.80 \pm 1.8$ & - \\
24 hours & $0.82 \pm 0.13$ & $0.73 \pm 0.12$ & - \\
Serum creatinine (mg \% $\%$ S.D.) & $0.85 \pm 0.21^{*}$ & $0.69 \pm 0.13$ & - \\
Control & & \\
\hline
\end{tabular}

*Statistically significant difference from the $\mathrm{N}_{2} \mathrm{O}$ group.

physiological testing remains to be seen, but it seems clinically obvious that it is better for a baby in the nursery to be awake, alert and normotonic rather than drowsy and hypnotic. Even transient alterations in central nervous system function in the newborn period may have far-reaching implications in terms of subsequent behavioural and neurological development. ${ }^{14}$ In the immediate neonatal period, poor neurological function may result in poor feeding and poor maternal-child interaction. ${ }^{1 \mathrm{~T}}$

The epidural group tended to be similar to the MOF group with the major difference being in the assessment of muscle tone. Our patients all received lidocaine for their epidural anaesthesia, and the results agree with those published by Scanlon for babies of mothers receiving lidocaine. ${ }^{13}$ The babies could generally' be classified as "alert but floppy."

There was no indication that fluoride-jnduced nephrotoxicity was a danger in the mother, with all patients being well below the accepted toxic level of 80 to $100 \mu$ mol. $^{18}$

\section{SERUM FLUORIDE LEVELS}

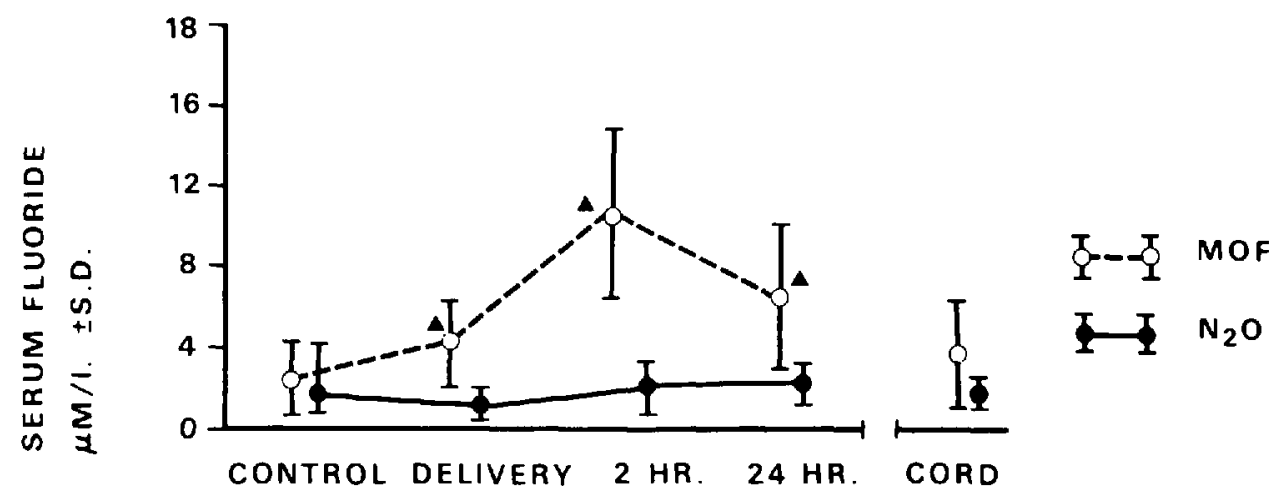

Ficure 1 . Serum fluoride levels in patients receiving methoxyflurane or nitrous oxide aniesthesia. $\Delta=$ Significantly increased from control. 


\section{MUSCLE TONE}

6 HOURS

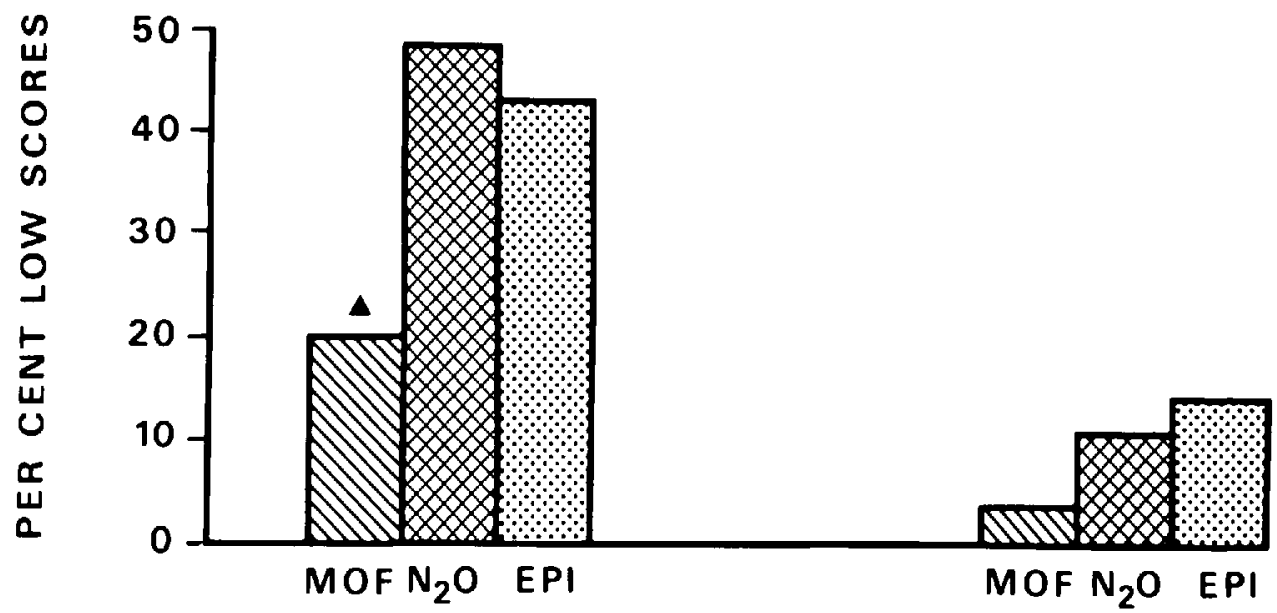

Figune 2. Per cent of babies exhibiting poor muscle tone in arms, legs, trunk at six and twenty-four hours after delivery. The methoxyflurane group is significantly better at six hours. $\Delta=$ Significantly different than the other two groups.

\section{REFLEX ACTIVITY}

\section{HOURS}

\section{HOURS}

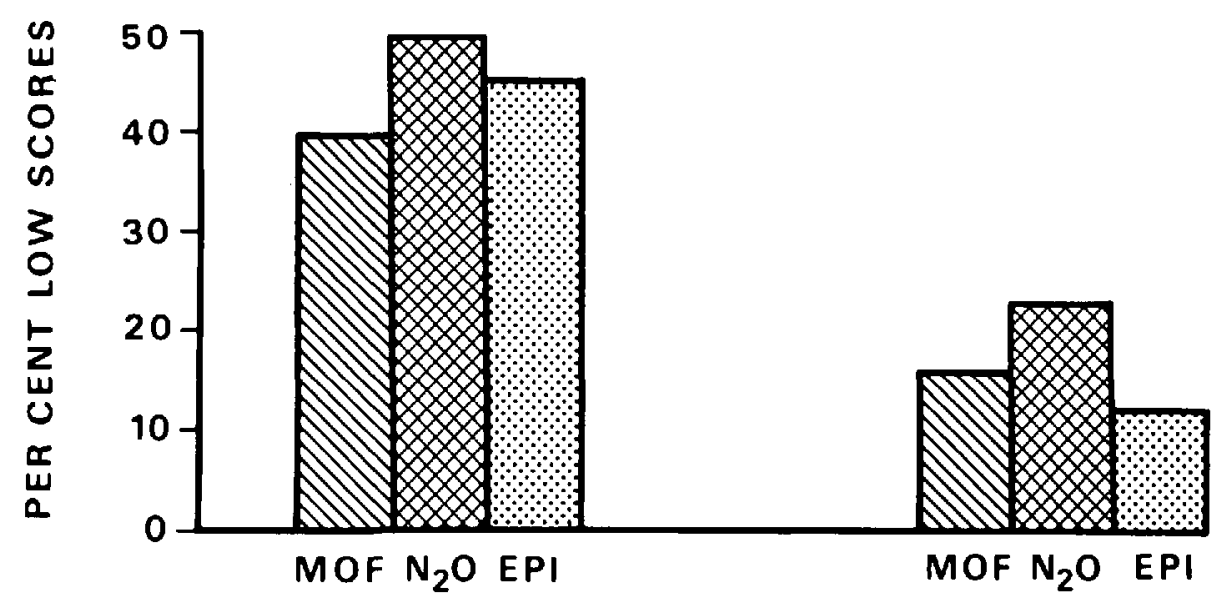

Figure 3. Per cent of babies exhibiting low scores in testing of Moro, sucking and rooting reflexes at six and twenty-four hours of age. There is no significant difference between the groups. 


\section{RESPONSE TO STIMULI}

6 HOURS

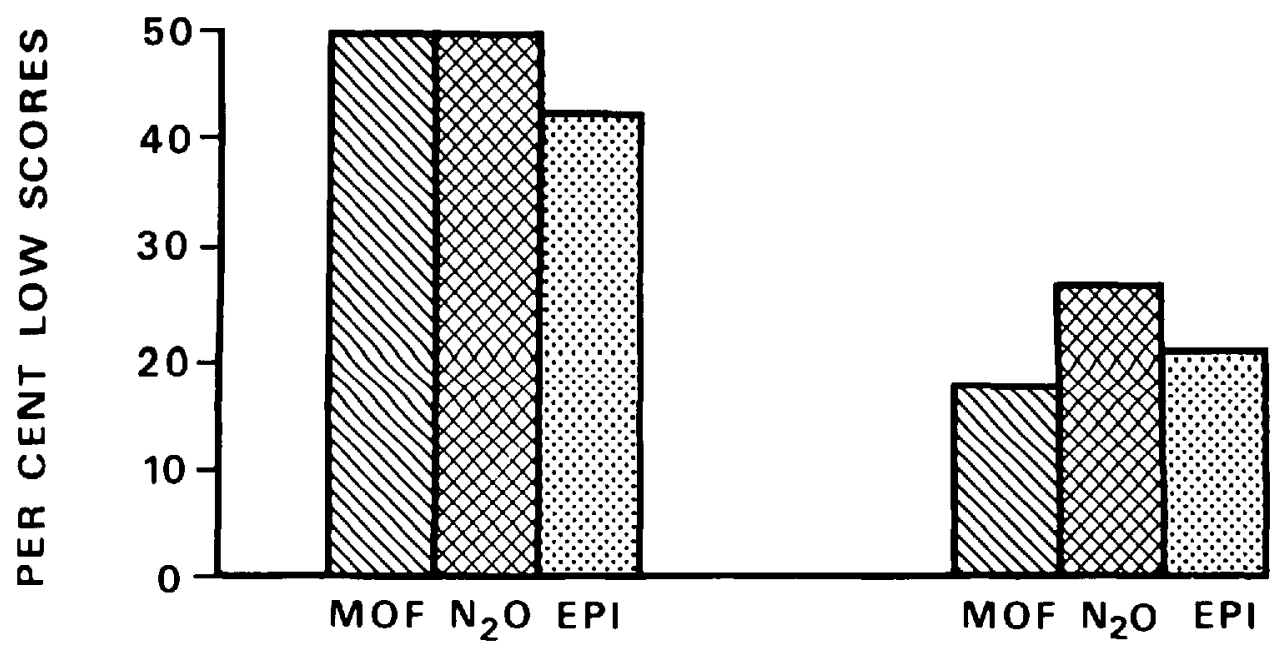

24 HOURS

Figure 4. Per cent of babies exhibiting low scores in response to pin prick and sound at six and twenty-four hours of age. There is no significant difference between the groups.

\section{ALERTNESS}

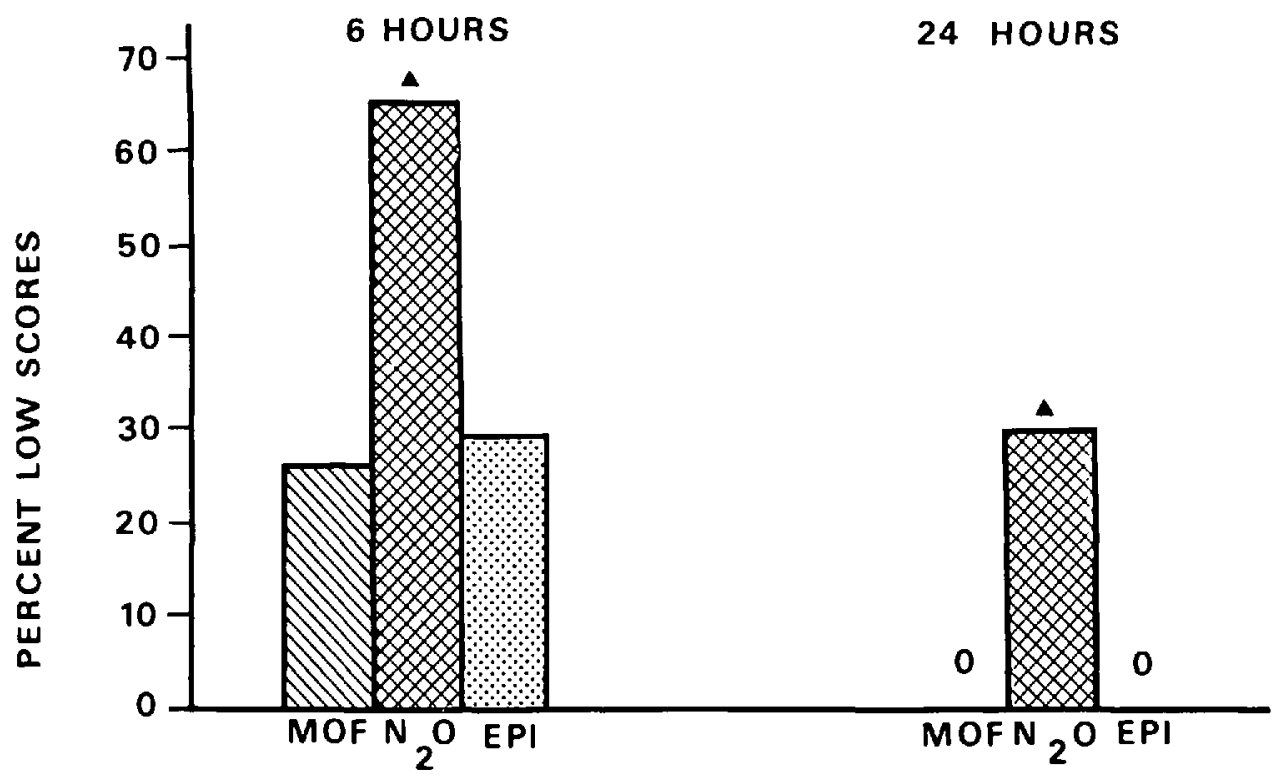

Figure 5. Alertness at six and twenty-four hours of age. The nitrous oxide group is significantly poorer at six and twenty-four hours of age. $\Delta=$ Significantly different than the other two groups. 


\section{GENERAL ASSESSMENT}

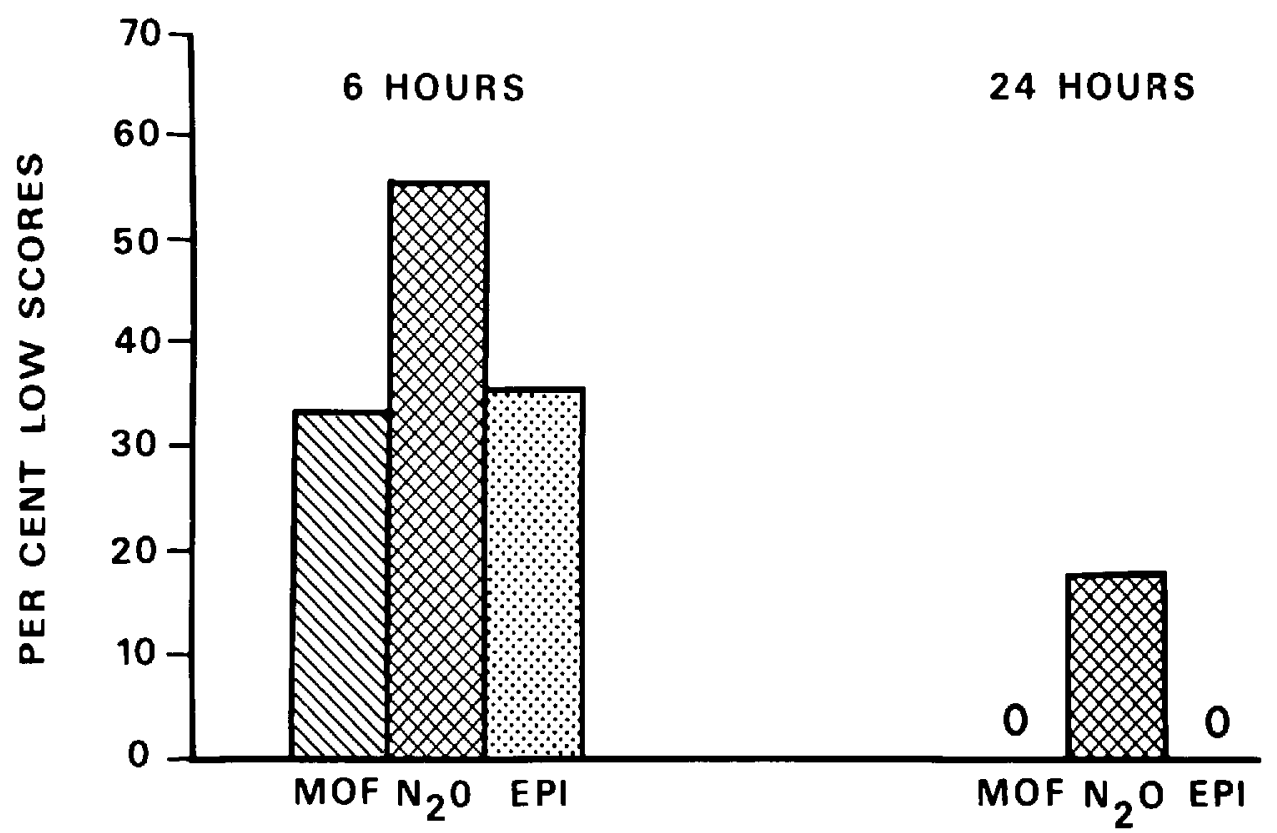

Figure 6. General assessment of the neonates at six and twenty-four hours of age. There is no significant difference between the groups, although the $\mathrm{N}_{\mathrm{O}} \mathrm{O}$ group assessment approaches significance at 24 hours $(0.05<\mathrm{P}<0.10)$.

Because of the possible long-term effects of depression in the neonatal period, we are obliged to administer the anaesthetic for Caesarean section which best combines matemal safety with neonatal well-being. The present study indicates that increasing the maternal $\mathrm{F}_{\mathrm{O}_{2}}$ by avoiding nitrous oxide may meet these requirements. Epidural anaesthesia with agents which do not reach the foetus in high concentrations (2-chlorprocaine or bupivacaine) may avoid the newborn hypotonia seen in this study. ${ }^{19}$

Although only elective Caesarean sections were considered in this study, in cases of urgent or emergency Caesarean section where there is evidence of foetal distress, it may be much more important to administer a high $\mathrm{FI}_{\mathrm{O}_{2}}$ to the mother in order to protect the foetus and neonate. ${ }^{20}$

\section{SUMMARY}

General anaesthetic techniques continue to be used for Caesarean section despite the possible increased incidence of foetal acidosis and neonatal depression. Two techniques of general anaesthesia (methoxyflurane-oxygen and nitrous oxideoxygen) and lumbar epidural anaesthesia were compared in 37 patients undergoing elective Caesarean section. Apgar scores at birth were similar in all three groups. Neurophysiological testing of the neonates at six hours and twenty-four hours of age revealed a superiority for the methoxyflurane-oxygen and lumbar epidural techniques, although the babies in the epidural group tended to be hypo- 
tonic. Curd blood gas analysis showed the babies in the methoxyflurane group to have a higher $\mathrm{PaO}_{2}$ with less metabolic acidosis than the babies from the other two groups. The maternal effects of the three anaesthetic techniques were similar, with only a small rise in serum fluoride levels noted in the methoxyflurane group.

\section{RÉSUMÉ}

L'anesthésie générale est encore d'usage courant pour les cas de césariennes malgré une incidence plus fréquente d'acidose foetale et la possibilité de dépression du nouveau-né. Deux techniques d'anesthésie générale, le methoxyfluraneoxygène et la protoxyde d'azote-oxygène, ainsi qu'une technique d'anesthésie régionale, soit l'épidurale lombaire continue, ont été étudiées et comparées au cours de 37 cas de césariennes.

Les résultats du score Apgar ont été semblables avec les trois méthodes. L'évaluation neuro-physiologique des nouveau-nés 6 heures et 24 heures après la naissance montrait la supériorité de l'anesthésie au methoxyflurane-oxygène et de l'épidurale sur la troisième technique; les bébés du groupe de l'épidurale avaient, en général, tendance à être hypotoniques.

Les gazométries effectuées sur le sang du cordon ombilical montraient une Po.. plus élevée et moins d'acidose métabolique après une anesthésie au methoxyflurane-oxygène qu'avec les deux autres méthodes. Du côté maternel, les effets étaient à peu près semblables sauf pour une petite élévation des fluorures sériques dans le groupe anesthésié au methoxyflurane.

\section{ACKNOWLEDGEMENT}

The authors would like to thank Miss Maureen Cumming for her invaluable technical assistance.

\section{REFERENCES}

1. Cosmi, E.V. \& Marx, G.F. Acid-base status of the fetus and clinical condition of the newborn following Cesarean section. Am. J. Obstet. Gynecol. 102: 378 (1968).

2. Benson, R.C., Berendes, H., \& Weiss, J. Fetal compromise during elective Cesarean section. Am. J. Obstet. Gynecol. 103: 570 (1969).

3. Shnider, S.M. Anesthesia for elective Cesarean section, Obstetrical Anesthesia. Edited by S.M. Shnider. Baltimore, Williams and Wilkins. pp. 94-105 (1970).

4. Fothengill, R.J., Robertson, A., \& Bond, R.A. Neonatal acidaemia related to procrastination at Caesarean section. J. Obstet. Gynaecol. Br. Comm. 78: 1010 (1971).

5. Tенамо, K. Foetal acid-base values during Caesarean section. Lancet 2: 1146 (1968).

6. Crawrond, J.S. Awareness during operative obstetrics under general anaesthesia. Br. J. Anaesth. 43: 179 (1971).

7. MAnX, G.F. \& MATEO, C.V. Effects of different oxygen concentrations during general anaesthesia for elective Caesarean section. Canad. Anaesth. Soc. J. 18: 587 (1971).

8. Khazin, A.F., Hon, E.H., \& Hehre, F.W. Effects of maternal hyperoxia on the fetus. I. Oxygen tension. Am. J. Obstet. Gynecol. 109: 628 (1971).

9. Crawford, J.S., Bunton, M., \& Davies, P. Anaesthesia for section: further refinements of a technique. Br. J. Anaesth. 45: 726 (1973).

10. Heese, H. DeV., Davey, D.A., Rorke, M., \& Molteno, C. Effect of maternal anaesthesia on oxygenation and acid-base status of the newborn infant. South African Medical Journal 47: 1991 (1973).

11. Morr, D.D. Anaesthesia for Caesarean section: An evaluation of a method using low concentrations of halothane and 50 per cent oxygen. Br. J. Anaesth. 42 : 136 (1970). 
12. Latro, I.P. \& Wainwright, A.C. Anaesthesia for Caesarean section analysis of blood concentrations of methoxyflurane using 0.1 per cent methoxyflurane and 40 per cent oxygen. Br. J. Anaesth. 44: 1050 ( 1972 ).

13. Scanlon, J.W., Brown, W.U. Jr., Weiss, J.B., \& Alper, M.H. Neurobehavioural responses of newborn infants after maternal epidural anesthesia. Anesthesiology 40: 121 (1974).

14. Moreau, T. \& Birch, H.G. Relationship between obstetrical general anaesthesia and rate of neonatal habituation to repeated stimulation. Dev. Med. Child. Neurol. 16: 612 (1974).

15. Brackbill, Y., Kane, J., \& Manniello, R.L. Obstetric premedication and infant outcome. Am. J. Obstet. Gynecol. 118: 377 (1974).

16. Fry, B.W. \& Taves, D.R. Serum fluoride analysis with the fluoride electrode. I. Lab. Clin. Med. 75: 1020 (1970).

17. Durowitz, V. Neurologic fragility in the newborn: influence of medication in labour. Br. J. Anaesth. 47: 1005 (1975).

18. Cousins, M.J. \& Mazze, R.I. Methoxyflurane nephrotoxicity: a study of dose response in man. J.A.M.A. 225: 1611 (1973).

19. Scanlon, J.W., Osthemen, G.W., Lurie, A.O., Brown, W.U., Weiss, J.B., \& Alper, M.H. Neurobehavioural responses and drug concentrations in newborns after maternal epidural ane: thesia with bupivacaine. Anesthesiology 45: 400 (1976).

20. Morishima, H.O., Daniel, S.S., \& Richards, R.T. The effect of increased matemal Pain. upon the fetus during labor. Am. J. Obstet. Cynecol, 123: 257 (1975). 